321.74:061.1EU(510)

https://doi.org/10.18485/fb_kpk100nsp.2021.ch13

Вељко Благојевић

\title{
Перцепција кинеског социјализма у ЕУ - стратешка перспектива
}

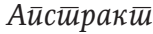

У раду се анализира контекст у коме се формирала Европска унија, њена стратегија заједничке спољне и безбедносне политике и њено настојање да се у међународним, или барем економским, односима све интензивније појављују као самостални глобални актер. Затим ће се укратко сагледати кључне стратегијске одлуке кинеског државног руководства које су довеле до тзв. кинеског економског чуда и како то види Европска унија. Основно питање је свакако будућност стратегијских односа Европске уније и социјалистичке Кине и који ће кључни фактори стратегијског окружења утицати на њен квалитет.
\end{abstract}

Кључне речи:

заједничка спољна и безбедносна политика Европске уније, социјалистичка Кина, стратегија, међународни односи, глобални процеси дугог трајања

\section{О СТРАТЕГИЈСКОМ ПОЗИЦИОНИРАњУ ЕВРОПСКЕ УНИЈЕ}

Многи теоретичари међународних односа, поготово они који се баве стратешким студијама, сматрају да је европска стратегијска мисао у озбиљној кризи. Чини се да је криза још више продубљена након што су грађани Француске и Холандије одбили сагласност за усвајање тзв. Устава Европске уније. Тако је 2005. године и формално прекинут процес даље федерализације Уније, што је имало додатне негативне ефекте на стратегијску мисао у Европи. 
Многи теоретичари међународних односа, углавном присталице реалистичке школе, сматрају да су Европљани изгубили нагон за развојем и да се налазе у стадијуму дубоке инерције, без великих амбиција за стратегијско промишљање и деловање, за разлику од Сједињених Држава, које демонстрирају узорну способност за прилагођавање савременим условима на међународној сцени. Они сматрају да се Европска унија на необјашњиво инертан начин односи према проблемима у међународној политици и да се чини да напушта глобалну геополитичку арену. Указују на слабљење њеног спољнополитичког утицаја, компромитовање европских вредности, структуралне пропусте у Уговору из Мастрихта, недовољно ефикасног управљања, јачању унутрашње хетерогености проузроковане постбиполарном експанзијом Уније и, чини се, свеукупним умором и неспремношћу за борбу на унутрашњем и глобалном плану. Све наведено је довело Европску унију на стадијум у коме се данас налази, без Британије која је напустила Унију и са мноштвом проблема на које све чешће нема заједничког одговора. Примера ради, годинама се тражи консензус о заједничком одговору на мигрантску кризу која је била масовна појава још 2015. године. Реакције појединих држава чланица Европске уније на почетку пандемије вируса COVID-19 указују на кључне ставове наведених теоретичара о процесима који се догађају у Европској унији.

Иако се већина на први поглед може сложити са наведеним ставовима у вези са стратегијским деловањем Европске уније, питање захтева нешто дубљу анализу за коју је неопходно враћање у саме корене теоријског схватања стратегије. Наиме, сви ћемо се сложити да је теорија стратегије у суштини теорија акције и око наведеног става чини се да нема никаквог несагласја. Ипак, то се често схвата у њеном ужем смислу, односно само као осмишљавање деловања, а изоставља уздржавање од предузимања акције, што је такође садржај предмета истраживања стратегијских студија посебно у домену такозваних великих стратегија у доба глобализованих међународних односа. Замислите како би изгледала међународна политика када би сваки њен субјекат деловао на удаљене догађаје „широм земаљскога шара”. Дакле, јасно је да субјекти међународне политике својим стратегијским деловањем успостављају приоритете у складу са којим делују на међународној сцени. Ти приоритети су, наравно, усклађени са унутрашњим уређењем субјеката међународне политике и њиховим виталним интересима.

Када на овај начин сагледавамо стратегијско промишљање и деловање Европске уније у међународној политици, отвара се нешто другачија перспектива и резултати анализе даће нешто другачије резултате. Условно можемо тврдити да је Европска унија настала на теоријским 
основама либералних идеја друштвеног развоја, људским правима, међусобној солидарности и правном уређењу унутрашњих односа, а на спољнополитичком плану на ефикасном мултилатералном деловању заснованом на међународном праву. Настанак и историјски развој Европске уније везан је за прилике у Европи након Другог светског рата и хладноратовску поделу света, у којој је ратом разорена Западна Европа видела шансу за помирење, економски и политички просперитет са снажним ослонцем на Сједињене Државе у економском и безбедносном сектору.

Америка је са Трумановом доктрином и Маршаловим планом кључно одредила правац, смер и динамику економског опоравка Европе (Гедис, 2003, стр. 65)1. Како је амерички државни секретар Џорџ Маршал (George Marshall) нагласио да програм није усмерен ка одређеној земљи или доктрини, већ против сиромаштва, очаја, беде и хаоса. Упркос овој идеалистичкој перспективи, главни циљ економске политике био је помоћ ратом уништеним земљама Европе да „устану” како би се сузбила совјетска (комунистичка) претња. Страхови од совјетског агресивног понашања на међународном плану додатно су ојачали након државног удара у Чехословачкој 1948. године, што је резултирало и формирањем Северноатлантског савеза (НАТО) годину дана касније. Разматрања стратегијских опредељења Европске уније без калкулације која се односи на интересе и стратегијске оријентације САД/НАТО не би дале адекватне резултате јер је реч о евроатлантском партнерству са дугом традицијом (Институт за стратегијска истраживања, 1988, стр. 17; Кисинџер, 1999, стр. 403-406). ${ }^{2}$

1 Стратегијски посматрано, Маршалов план био је један од првих инструмената обуздавања који је стављао акценат на њену економску димензију. После Другог светског рата Вашингтон је тежио да створи систем политичког самоопредељења кроз економску интеграцију. Такав систем би се заснивао на заједничким интересима који би неминовно довео до повезивања са другим државама. Маршалов план је подстакао развој демократије међу западноевропским државама путем њиховог економског опоравка.

2 НАТО је један од првих савеза формиран у мирнодопском периоду у америчкој историји. Иако западни аутори, попут Гедиса и Кисинџера, обично воле да истакну одбрамбену и мирну природу НАТО, истина је нешто другачија. Иако се НАТО сам по себи појавио као одбрамбени савез, његове намере не могу се класификовати искључиво као одбрамбене. Америчка војна доктрина, коју је Пентагон представио у виду „Упутства о смерницама за развој војне силе” (Directive Instructions upon the Development of the Military Force), садржи два специфична сегмента који истичу офанзивне намере САД и НАТО. Према првом, од суштинског је значаја да САД превлада СССР у најкраћем временском периоду и потчини Совјете. Основни циљ је био да политичко-војне структуре СССР лиши капацитета за вођење рата уништавањем њихових индустријских центара, надајући се да ће САД моћи 
Иако је НАТО био важан за америчку спољну политику, идеја о савезу није била наметнута силом, већ су га европске државе прихватиле добровољно, као бољу алтернативу у односу на совјетске услове (Ball, 2014, pp. 81-83). Европљани су брзо схватили опасности од совјетске претње, не толико у смислу реалполитике и освајања, већ зато што је СССР претио да ће променити сам темељ њиховог начина живота. Због антиауторитарне прошлости Америка се чинила бољом алтернативом у поређењу са Варшавским пактом. Гадис чак тврди да је иницијатива НАТО заправо била европска иницијатива од почетка, јер је Западна Европа позивала ваневропску велику силу да успостави зону утицаја која би и њих ставила под заједнички безбедносни кишобран (Гадис, 2003, стр. 80-85).

Након краја Хладног рата и победе демократије, односно либералних идеја које је представио Францис Фукојама (Francis Fukuyama) у делу „Крај историје и последњи човек”, могло се очекивати да је дошло време да се Европска унија осамостали и у безбедносном смислу јер је нестала совјетска претња због које је НАТО и основан. Међутим, то се није догодило и НАТО је наставио, са политиком „отворених врата", своје ширење на Исток, што је у крајњем довело до супротстављања Русије и савремене кризе у односима Запада и Руске федерације. Тежње Европске уније да стекну већу самосталност у спољној и безбедносној политици су и даље објективно ограничене, што се најочигледније може видети кроз споразум тзв. Берлин плус формиле. ${ }^{4}$

издржати нуклеарни сукоб. Други став наводи потребу за првим нуклеарним ударом, односно намера да САД треба да буду сила која прва лансира нуклеарни удар. Стога је од суштинске важности имати нове нуклеарне инсталације широм Европе, истовремено проширујући развој модерних стратешких система попут Минутемана или Тридента.

Из ових редова јасно се могу уочити офанзивне намере САД које су се неизбежно пренеле и на НАТО, чији су неприкосновени лидер.

3 Важност НАТО за америчку спољну политику је заиста неупитна. Међутим, према Белу, савез је био у супротности са демократским постулатима западног друштва. Алијансе за правилно функционисање морају бити засноване на облику колективне малоумности. Другим речима, стратегије које управљају таквим савезима дизајниране су у складу са најнижим имеником трошкова и највишим именитељем интереса, пратећи понашање непријатеља. Демократија која пропагира морал и принципе у политици чини војне савезе веома тешким. Демократија често може ограничити стратешко размишљање или стратешке могућности војног савеза. Совјети су имали много лакши задатак да дефинишу холистички стратешки приступ у Варшавском пакту за разлику од Американаца у НАТО.

4 Реч је о споразуму између НАТО и ЕУ који, између осталог, подразумева прече право НАТО да се изјасни да ли има интерес да се ангажује у некок кризи, а тек након тога се могу самостално ангажовати снаге Европске уније, коришћење НАТО 
Европска унија се економски и политички развијала умногоме захваљујући и мањим издвајањима за одбрану и безбедност, јер су јој Сједињене Државе пружале безбедносне гаранције. Истовремено, Европска унија више од пола века није била у позицији да самостално разматра свој свеукупни стратегијски положај и деловање на међународној сцени, иако се у наведеном периоду може пратити константно настојање да се заједнички ангажују државе чланице Уније на безбедносном и политичком плану (Савић, 2013). Усвајање Глобалне стратегије спољне и безбедносне политике Европске уније 2016. године најављује већи степен њене самосталности у међународној политици, уз све њене предности на економском и политичком плану, али и неке недостатке у области одбране и безбедности. Можда је кључна одредница стратешке културе Европске уније презентована у наведеном документу, њено инсистирање на моралним принципима и начелима спољне политике и међународном праву, у складу са идеолошким одредницама на којој је и формирана, а не на реалполитици и геополитичким интересима (Laidi, 2008, pp. 125-135; Manners, 2002, pp. 235-258). Остаје питање како ће Стратегија реализовати своје опредељење за већим ангажовањем у међународној политици у савременим условима јачања реалполитике у међународним односима и најава промена глобалног поретка из униполарног у мултиполарни, у коме се Кина све чешће намеће као предводница изазивача глобалном хегемону, хтела она да прихвати тај статус или не. Због тога је однос Европске уније према савременој Кини значајан и то ће бити константа и у годинама које долазе.

Чини се да Европска унија перципира савремену Кину превасходно као прворазредну економску силу, чији економски развој више није могао да се не занемарује, што је било њихово стратегијско опредељење дужи низ година. Постоје ту и одређене сличности у историјском контексту, јер и Европска унија и Кина свој положај у међународном поретку могу да „захвале” управо економској моћи, с тим да је ЕУ то учинила умногоме захваљујући САД, а Кина самосталним и дугорочним процесом привредних реформи које је предводила социјалистичка власт.

ресурса и капацитета за мисије и операције ЕУ, размену поверљивих података и слично. 


\section{УСПОН СОЦИЈАЛИСТИЧКЕ КИНЕ}

Кинеска економска реформа, која је започета 1978. године, и њени заиста импресивни резултати постепено су доводили до све већег отварања Кине према свету и њеној све значајнијој улози у међународним односима. Кинеска привредна реформа реализована је кроз три основна стуба, а све у складу са принципима „четири модернизације”, који се односе на унапређење 1) пољопривреде, 2) индустрије, 3 ) науке и образовања и 4) националне одбране, а у складу са старим концептом социјалистичке модернизације (Митровић, 1995, стр. 35-145).

Након деценије успешне реализације првог стуба привредне реформе (пољопривреда), средином осамдесетих година прошлог века јача индустријски сектор, који са собом доноси одређене проблеме које социјалистичко руководство Кине превазилази увођењем мера којима се систем прилагођавао моделу који је далеко више био заснован на тржишним принципима и комерцијализацији, за разлику од командне економије и заједничког и државног власништва који доминирају пре отпочињања реформи. Лидер Комунистичке партије Денг Сјаопинг (Deng Xiaoping) je 1984. године позитивна искуства које је Кина стекла реформама описао следећим речима: „Искуство током минулих тридесет или више година показало је да би политика затворених врата отежала изградњу и кочила развој" (Li, Venli, 2015, p. 154).

Кинеско отварање према свету одвијало се у оквиру пројекта „Једна земља, два система", што је омогућавало експериментални развој тржишне економије у обалским областима. Истовремено, модел је био привлачан за страна улагања, која су могла да буду реализована кроз опцију предузећа у искључиво страном власништву, у заједничком власништву, односно кроз неке посебне уговорне јединице за прераду и склапање неких врста производа или имати друге облике.

Захваљујући трећем стубу економских реформи (образовање и наука) Кина је успешно превазишла фазу економске сарадње која је трајала од деведесетих година прошлог века и заснивала се на понуди јефтине радне снаге за индустријску производњу. Кина је данас једна од водећих држава са сопственом научном базом за развој софицистираних и технолошки високоразвијених добара и услуга, који укључују и сателитске комуникације и свемирске истраживачке програме.

Европска унија је у то време сматрала да ће се сменом социјалистичке власти догодити и проблеми на унутрашњеполитичком плану у Кини, што је био „стратегијски ехо совјетског случаја” који није био примерен успесима Кине на унутрашњеполитичком плану. Истовремено, током деведесетих година се веровало да социјалистички модел управљања не 
нуди могућности за економски развој, па је Европска унија у складу са њеним либералним фундаментима веровала да без демократије западног модела нема економског просперитета. Сведоци смо да се ништа од стратегијских процена Европске уније није остварило и да је Кина наставила за убрзаним економским развојем и јачањем утицаја на међународну политику.

Иницијатива првобитно названа на енглеском језику „Један појас, један пут”, а затим преименована у Иницијативу „Појас и пут”, програмски је разрађена у марту 2015. године у документу названом "Визије и акције о заједничкој изградњи Економског појаса пута свиле и Поморског пута свиле за 21. век". Претходно је на Трећој пленарној седници 18. сазива ЦК КПК, одржаној у новембру 2013. године, донета одлука да се убрза инфраструктурно повезивање на регионалном нивоу, при чему су „Економски појас пута свиле” и „Поморски пут свиле за 21. век” наглашени као приоритети у контексту политике реформи и отварања (Mitrović, 2018, p. 18). О грандиозности наведеног пројекта и његовог географског домашаја најбоље говори мапа која следи.

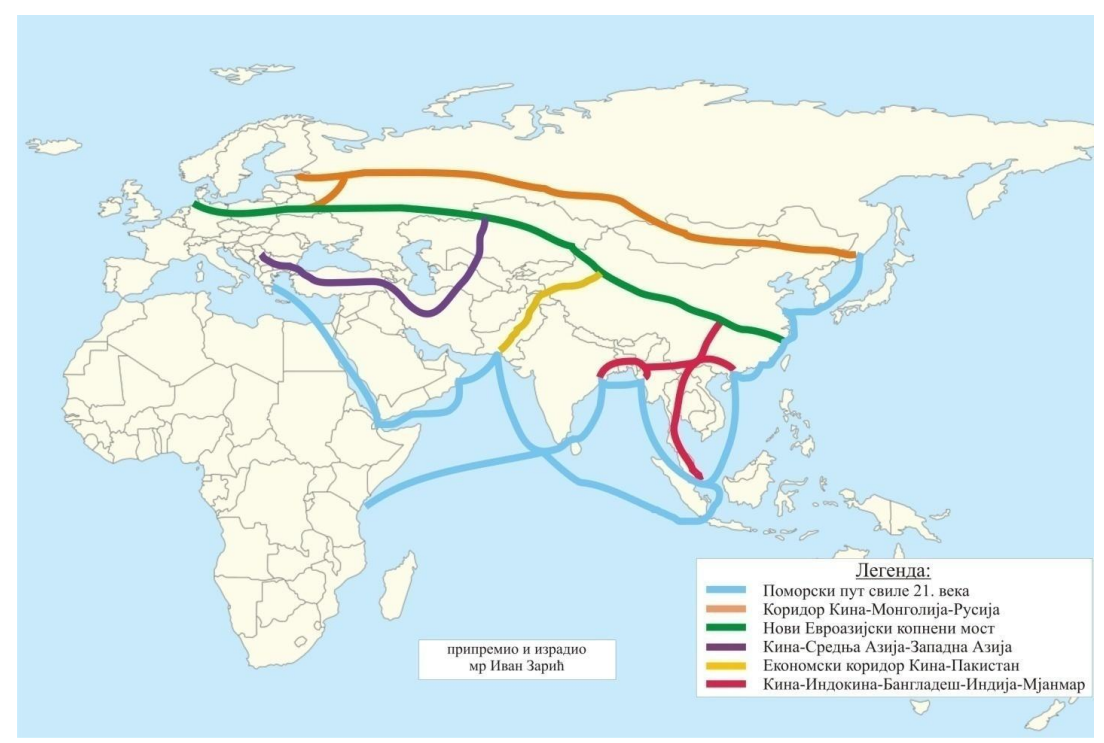

Приказ копненог и поморског пута свиле (Зарић, 2018, стр. 154)

Политика реформи и отворених врата довела је до великих промена у кинеском промишљању о њеној геоекономској позицији у свету. Тако је један од механизама који је успостављен био усмерен и на подручје 
сарадње у оквиру пројекта „Кина + 16 земаља Средње и Источне Европе". У оваквој ситуацији Европска унија више није могла да настави да практикује своје досадашње стратегијско опредељење и не реагује на Кину као економског џина глобалних размера, изузев појединачних опаски у вези са нелојалном конкуренцијом, заштитом патената и ауторских права и основних људских права (Митровић, 2015).

Сведоци смо да је Европска унија током последњих неколико година преговарала са Кином о економском споразуму који би омогућио њихова улагања на кинеском тржишту под условима домаћих инвеститора, како би се донекле избалансирао трговински биланс. Крајем прошле године Кина је упутила позив Европској унији да заједнички помогну Африци и Латинској Америци, са намером да се значајније афирмишу на међународном плану и стратешки држе подаље од стриктног везивања за Сједињене Државе (Xinua, 2021). Почетком 2021. године потписан је Свеобухватни уговор о улагањима, који је усложио не само односе између САД и Европске уније, већ и унутар држава чланица. Процес ратификације унутар Европске уније је под знаком питања и условљава се питањима људских права и слобода, разних санкција и слично. Истовремено, Сједињене Државе и Европска унија најављују својеврсни контратег пројекту „Један појас, један пут” (Politico, 2021).

Посебно је значајно напоменути да се Европска унија наведеним економским споразумом ипак појављује као глобални играч и то у тренутку када је бивши председник САД Доналд Трамп (Donald Trump) напуштао позицију у Белој кући, а на његово место долазио демократа Џозеф Бајден (Joseph Biden), који се, за разлику од свог претходника, залаже за тешњу сарадњу са европским партнерима. Рекло би се да је одлазећа немачка канцеларка Ангела Меркел (Angela Merkel), која је подржала потписивање споразума са Кином, то учинила у стратешком моменту у коме би се негативне реперкусије његовог потписивања најмање одразила на сарадњу са САД.

\section{ЗАКЉУЧНА РАЗМАТРАЬА}

Потписивањем Свеобухватног споразума о улагањима са Кином Европска унија коначно је учинила први значајнији самосталан корак ка успостављању сарадње са социјалистичком Кином, који би могао да донесе корист потписницама не само на економском плану, већ и у сфери афирмације на пољу међународне политике као два мирољубива актера која су привржена међународном праву. На овај начин Европска унија 
настоји да што мање провоцира свог најзначајнијег евроатлантског партнера, али и настоји да води самосталнију спољну политику на глобалном нивоу и тиме обезбеди превасходно реализацију економских интереса.

Стратегијски односи између Кине и Европске уније умногоме ће зависити од будућих односа великих глобалних геополитичких играча на евроазијском простору, посеб́н на релацији НАТО-Русија, али и односа САД и Кине у погледу развоја ситуације у кризним регионима Јужног кинеског мора. Европска унија нема капацитете да се на светској сцени појави као самосталан геополитички играч, изузев у економској моћи, па је и због тога за очекивати дугорочан наставак евроатлантске сарадње која има дугу и плодотворну традицију.

Ипак, уколико процес слабљења америчке моћи буде настављен, не би требало да буде изненађење јачање односа сарадње Европске уније и Кине. Такав развој догађаја на глобалној међународној сцени, чини се, нужно мора да прати и побољшање односа између Европске уније и Русије како Унија не би имала свеприсутан безбедносни императив сарадње са Сједињеним Државама. Свакако, јасно је да је будућност односа Европске уније и Кине скопчана са кључним геополитичким процесима савременог доба који ће одредити судбину глобалног лидерства. Хоће ли стара и помало посустала госпођа Европа, како је називају њени прекоокеански партнери, још једанпут успети да се правилно стратегијски определи у складу са кључним геополитичким процесима које доноси будућност остаје да се види, али је, чини се, извесно да ће социјалистичка Кина у њој играти значајну улогу.

\section{ЛИТЕРАТУРА}

1. Ball D. (2014). Power and International relations. Canberra: ANU Press.

2. Гедис Џ. Л. (2003). Хлаgни рай: Ми gанас знамо. Београд: CLIO.

3. Зарић И. (2018). Таласокрайска gимензија савремене кинеске іеойолийике, докторски рад. Београд: Факултет политичких наука.

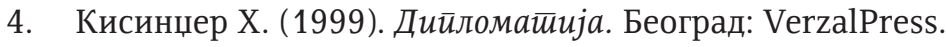

5. Laïdi Z. (2008). Norms over Force - The Enigma of European Power. New York: Palgrave Macmillan.

6. Ли, В., Венли Ж. (2015). Савремена кинеска економија. Београд: Албатрос Плус. 
7. Manners I. (2002). Normative Power Europe: A Contradiction in Terms? Journal of Common Market Studies, Vol. 40 (2), 235-258.

8. Митровић Д. (1995). Кинеска реформа и свети: економско и йолийичко окружење Кине у 80-им іоgинама. Београд: Институт за економику и финансије.

9. Mitrović D. (2018). China's Silk Road Initiative: Connecting and Transforming Initiative. In The Belt \& Road Initiative in the Global Arena: Chinese and European Perspectives. Singapore: Palgrave Macmillan.

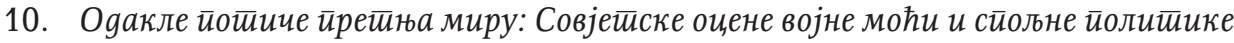
САД (1988). Београд: Институт за стратегијска истраживања.

11. Савић С. (2013). Сйубови евройске безбеgностии на йочейку 21. века. Београд: Медија центар Одбрана.

\title{
Иниеернети извори
}

1. Митровић Д. (2015). Кинески уйии,ај на земље ЕУ йосйаје све јачи. httр:// www.portalnovosti.com/dragana-mitrovic-ki-neski-uticaj-na-zemlje-eu-a-postaje-sve-jaci (06.07.2021).

2. Xi calls for expanding consensus, cooperation with Europe in virtual summit with French, German leaders. http://www.xinhuanet.com/english/2021-07/06/c_1310044528.htm (05.07.2021).

3. EU starts work on rival to China's Belt and Road Initiative, internet; https:// www.politico.eu/article/eu-starts-work-on-rival-to-chinas-belt-and-roadproject-network/ (05.07.2021).

Veljko Blagojević

\section{PERCEPTION OF CHINESE SOCIALISM IN THE EU - STRATEGIC PERSPECTIVE}

\begin{abstract}
The paper analyzes the strategic context in which the European Union was formed, its Strategy of Common Foreign and Security Policy and its efforts to appear more intensively in international relations as an independent global actor in sense of strategic means and ways of its implementation. The analysis of these factors has created solid conditions for understanding the key determinants of its strategic perception of modern socialist China. European Union and China share similar official conceptual views on future international relations based on peaceful ways of resolving international disputes, international law and their international power are predominantly based on economy. One can expect mutual
\end{abstract}


cooperation of economic and peaceful powers. However, there are a lot of strategic reasons to believe that EU will follow US policy toward socialist China in the future if there are no huge turbulences in Euro Atlantic relations.

\section{Keywords:}

EU Common Foreign and Security Policy, Socialist China, strategy, international relations, long-last global processes. 